ISSN 1984-3755

\title{
João XXIII, o papa do Concílio. "Veio um homem enviado por Deus cujo nome era João"
}

\author{
John XXIII, pope of the Council. "There came a man \\ sent from God whose name was John"
}

\begin{abstract}
Antonio José de Almeida
Doutor, mestre e graduado em Teologia pela Pontifícia Universidade Gregoriana de Roma; professor adjunto no Programa de Pós-Graduação em Teologia da Pontifícia Universidade Católica do Paraná (PUCPR); professor de Eclesiologia, Ecumenismo e Sacramentos no curso de graduação em Teologia da mesma Universidade, Curitiba, PR - Brasil, e-mail: ajacatedral@uol.com.br
\end{abstract}

\section{Resumo}

Caminho privilegiado para a compreensão do Concílio Vaticano II é sua relação com o papa que o anunciou, convocou e inaugurou. Percorrer a trajetória do Vaticano II desde seu anúncio, em 25 de janeiro de 1959 (festa da conversão de São Paulo), até a morte de João XXIII (Pentecostes de 1963) é revisitar - como que conduzido por um guia privilegiado - os primeiros e decisivos passos de um dos mais importantes acontecimentos da bimilenar história da Igreja. Infelizmente, João XXIII (1881-1963), a não ser pelo insólito e merecido epíteto de "papa bom”, é cada vez menos conhecido entre nós. Como, aliás, salvas as proporções, o próprio Concílio. 0 presente artigo ajuda a preencher tal lacuna, mostrando-nos a grandeza humana e cristã de João XXIII e a transcendência do seu ministério diante da Igreja de Roma num momento decisivo para ela e para a 
humanidade. “Quem viveu tanto e se encontrou, nos inícios do século XX, diante das responsabilidades novas de uma atividade social que investe o homem todo; quem esteve, como eu, vinte anos no Oriente, oito na França e pôde confrontar culturas e tradições diversas, sabe que chegou o momento de reconhecer os sinais dos tempos, de colher a sua oportunidade e olhar longe." (João XXIII, no leito de morte).

Palavras-chave: João XXIII. Igreja. Concílio. História.

\section{Abstract}

A privileged path to understand Vatican II Council is its relation with the pope who announced, convened and inaugurated it. Running through the trajectory of the Vatican II from its announcement, on January 25, 1959 (Party of the Conversion of St. Paul), to the death of John XXIII (Pentecost, 1963) is to revisit - as if conduced by a privileged guide - the first and decisive steps of one of the most important events in the two thousand year history of the Church. Unfortunately, John XXIII (1881-1963), except for the unusual and well deserved epithet "the good pope" is ever less known to us. As, indeed, kept the proportions, the Council itself. This article helps to fill this gap, showing us the human and Christian greatness of John XXIII and the transcendence of his ministry as the head of the Church of Rome at a decisive moment for it and for humanity. "He who lived so much and found himself, in early twentieth century, before the new responsibilities of a social activity that invests in man as a whole; he who has spent, like me, twenty years in the East, eight in France and could face diverse cultures and traditions, he knows that it is time to recognize the signs of the times, of collecting his opportunity and looking farther ahead." (John XXIII, on his deathbed).

Keywords: John XXIII. Church. The Council. History.

1959-2011. Cinquenta e dois anos se passaram desde o anúncio do Concílio Vaticano II pelo papa João XXIII. É mais que o espaço de duas gerações. Pode parecer pouco, mas, na aceleração da história em que vivemos de algumas décadas para cá, soam como o "naquele tempo" que abre a proclamação do Evangelho na santa liturgia. 
Os arquivos vaticanos sobre João XXIII só deverão ser abertos aos pesquisadores em 2038, quando ele completaria 157 anos, se tivesse tido a mitológica sorte dos patriarcas bíblicos. O último papa a ter seus arquivos abertos foi Pio XI (1922-1939), com a autorização, de praxe, dada pelo papa atual em 2006.

Não precisamos, porém, esperar tanto para traçar um despretensioso quadro das relações entre João XXIII e o Concílio por ele inaugurado, contribuindo, assim, queira Deus, a conhecê-los melhor. As fontes consultadas pertencem a três gêneros distintos: história, memória e hagiografia. Entre os textos históricos, estão alguns provenientes do Instituto de Ciências Religiosas, de Bologna, produzidos, sobretudo, pelo mais insigne dos seus representantes, o professor Giuseppe Alberigo (1926-2007) ${ }^{1}$. Na categoria memória, figuram, sobretudo, os "Ricordi dal concilio", do secretário particular de Roncalli de 1953 a 1963, Loris Francesco Capovilla, que hoje vive, carregando bem seus 95 anos, em Sotto il Monte, vilarejo natal de Angelo Giuseppe Roncalli (CAPOVILLA, 2011); e, finalmente, a biografia oficial para a beatificação de João XXIII (BENIGNI; ZANCHI, 2000). Nos últimos tempos, vem crescendo, porém, uma linha interpretativa, que discute os pressupostos, a metodologia e as conclusões da "escola de Bologna", sendo seu maior representante o historiador Roberto de Mattei, cuja obra Il Concilio Vaticano II. Una storia mai scritta recolhe e analisa, além dos arquivos e fontes, os diários, as crônicas e os testemunhos, um conjunto de obras que o instrumentam para uma "nova reconstrução e interpretação dos fatos” (DE MATTEI, 2011, p. 23)². A documentação é valiosa; a interpretação, radicalmente questionável.

1 Sabe-se que a "vida de João XXIII" do Instituto de Ciências Religiosas de Bologna não se pretende nem a única nem a melhor nem esconde a pré-compreensão com que trabalha: ALBERIGO, G. Papa Giovanni (1881-1963). Bologna: EDB, 2000; ALBERIGO, G. (Org.). Breve storia del Concilio Vaticano II (1959-1965). Italia: II Mulino, 2006; ALBERIGO, G. (Org.). Storia del Concilio Vaticano II. Bologna: EDB, 1995-2001. v. 5; ALBERIGO, G. (Org.). Jean XXIII devant I'histoire. Paris: Seuil, 1989; ALBERIGO, G. (Org.). História dos Concílios Ecumênicos. São Paulo: Paulus, 1995; ALBERIGO, G.; GIOVANNI XXIII, A. Profezia nella fedeltà. Brescia: Queriniana, 1978; ALBERIGO, G.; MELLONI, A. Fede tradizione profezia, studi su Giovanni XXIII e sul Concilio. Brescia: Morcelliana, 1984; BEOZZ0, J. 0. A Igreja do Brasil no Concílio Vaticano II (1959-1965). São Paulo: Paulinas, 2005; RONCALLI, M. Giovanni XXIII. Angelo Giuseppe Roncalli, una vita nella storia. Milano: Mondadori, 2006; MELLONI, A.; RUGGIERI, G. (Ed.). Chi ha paura del Vaticano II? Roma: Carocci, 2009.

2 Na mesma direção, embora de distintas fisionomias, podem-se arrolar textos como: WILTGEN, R. Le Rhine se jette 
A oportunidade para este nosso modesto trabalho é o aniversário, que se aproxima, dos 50 anos da solene abertura do Vaticano II (11 de outubro de 1962), que, certamente, suscitará novos estudos sobre a vida, a figura e a obra do Papa do Concílio.

\section{0 anúncio "programático"}

Era a tarde do dia 25 de janeiro de 1959, festa da Conversão de São Paulo. O papa encontrava-se numa pequena sala da abadia de "San Paolo fuori le mura", em Roma. Terminara a missa conclusiva da $51^{\text {a }}$ Semana de Oração pela Unidade dos Cristãos. Diante de um pequeno grupo de cardeais - 17 ao todo - João XXIII, consciente de ser "bispo de Roma e pastor da Igreja universal"3, traça um breve quadro da situação de Roma e do mundo, e conclui:

Esta constatação desperta no coração... uma resolução firme ("una risoluzione decisa") de apelar a algumas formas antigas de afirmação doutrinal e de sábios ordenamentos de disciplina eclesiástica, que, na história da Igreja, em época de renovação, deram frutos de extraordinária eficácia, pela clareza do pensamento, pela solidez da unidade religiosa, pela chama mais viva do fervor cristão... (GIOVANNI XXIII, 1989, p. 558).

dans le Tibre. Le Concile inconnu. Paris: Editions du Cèdre, 1976; BERGER, D. Gegen die Tradition oder im Licht der Tradition? Zu neueren Interpretationen des Zweiten Vatikanischen Konzils. Divinitas, n. 40, p. 293-316, 2005; MARCHETTO, A. II Concilio Ecumenico Vaticano II. Contrappunto per la sua storia. Città del Vaticano: Libreria Editrice Vaticana, 2005; GHERARDINI, B. Concilio Vaticano II. Un discorso da fare. Frigento: Casa Mariana, 2009.

3 Na sua primeira fala oficial depois de eleito, João XXIII apresentou-se como bispo de Roma. Alguns dias depois, na tomada de posse da basílica de São João do Latrão - catedral de Roma - destacou elegantemente como os seus predecessores houvessem omitido ou dado menor importância a tal ato, que ele queria resgatar no seu pleno significado: "o papa é autenticamente e não só simbolicamente bispo de Roma” (ALBERIG0, 2000, p. 140). "Sabe-se também que ele tinha pensado em dividir a sua residência entre o Vaticano e o Latrão, para mostrar que ele era bispo de Roma, mas isso não passou de um sonho (cf. GENNARI, G. Quando Ratzinger era considerato un 'pericoloso teologo d'oltralpe'. Disponível em: <Affari. It>. Acesso em: 25 mar. 2011). Não sendo isso viável, multiplicou suas visitas, públicas e privadas, a escolas, asilos, prisões, paróquias, graças ao que recebeu o jocoso apelido de "Giovanni fuori le mura" (cf. BENIGNI, M.; ZANCHI, G. João XXIII. São Paulo: Paulus, 2000. p. 267-271). Coerentemente com essa convicção, em 12 de junho de 1962, decidiu a transferência para São João do Latrão de toda a estrutura do Vicariato da diocese, acentuando a autonomia da cúria diocesana e traduzindo, também em nível burocrático, a unidade, a diferença e a articulação, na Igreja de Roma e na pessoa do seu bispo, das instâncias local e universal da Igreja (ALBERIG0, 2000, p. 178).

Rev. Pistis Prax., Teol. Pastor., Curitiba, v. 4, n. 2, p. 357-393, jul./dez. 2012 
Quais seriam essas instituições antigas que, "na história da Igreja, em época de renovação", deram tão formidáveis frutos? Salvo Tardini, o secretário de Estado, ao qual confidenciara, poucos dias antes, sua decisão, nenhum dos presentes podia suspeitar que instituições o papa tivesse em mente: "Pronunciamos diante de vós, certamente tremendo um pouco de comoção, mas, ao mesmo tempo, com humilde firmeza de propósito ("con umile risolutezza di proposito"), o nome e a proposta da dupla celebração: de um sínodo diocesano para a Urbe e de um concílio geral para a Igreja universal".

A festa da conversão de São Paulo - tinha dito o papa no início de sua fala:

nos sugeriu abrir a nossa alma confidente à vossa bondade e compreensão acerca de alguns pontos mais luminosos de atividade apostólica que estes três meses de presença e de contato com o ambiente eclesiástico romano nos sugeriram [...] em correspondência bem clara e definida do novo pontificado com as espirituais exigências da hora presente (ALBERIGO, 1978).

Algum tempo depois, já em 1961, o papa dirá que "o concílio pretende construir um edifício novo sobre os fundamentos colocados no curso da história... dilatará as dimensões da caridade às diversas necessidades dos povos e lhes proporá em modo claro a mensagem de Cristo" (GIOVANNI XXIII, DMC III, p. 503). Os fatores que fizeram amadurecer, em João XXIII, a ideia de celebrar o concílio como "a mais válida resposta colegial às expectativas" da Igreja e do mundo foram, segundo Capovilla (2011, p. 54),

o profundo conhecimento dos acontecimentos da Igreja, especialmente nos períodos cruciais das suas interiores transformações e evoluções; a consciência, teologicamente fundada, em modo particular, na leitura dos Padres, da corresponsabilidade colegial no governo da Igreja por parte de todo o episcopado e, de alguma maneira, de todo o povo de Deus; a fé certíssima e radical na assistência do Espírito Santo à sua Igreja, particularmente nos momentos de mais acentuada gravidade pastoral $[\ldots]^{4}$.

4 Roncalli tinha longa familiaridade com a história da Igreja (cf. MELLONI, A. Formation et développement de la culture de Roncalli. In: ALBERIGO, G. (Org.). Jean XXIII devant l'histoire. Paris: Le Seuil, 1989. p. 219-259). Dedicou-se especialmente ao estudo de São Carlos Borromeu (1538-1584) e do oratoriano cardeal Cesare Baronio (1538-1607), considerado o pai da moderna historiografia da Igreja, investigando os documentos 
O anúncio de um concílio ecumênico, por parte de um "papa de transição" e quase octogenário - mas consciente das suas prerrogativas primaciais, da natureza excepcional do próprio ato e do caráter definitivo da sua decisão - pegou a todos de surpresa.

\section{As primeiras reações}

"Humanamente" - dirá o papa em 8 de maio de 1962 - "poderia julgar-se que os cardeais, depois de escutarem a alocução, se apertassem em torno a Nós, exprimindo aprovações e augúrios. O que houve, ao invés disso, foi um impressionante devoto silêncio... Só nos dias seguintes obtivemos a explicação, quando os purpurados presentes à audiência nos falaram em particular. 'Foi tão intensa a comoção e tão profundo o gozo... que não encontramos palavras adequadas para manifestar o júbilo e a obediência ilimitada""5.

Outras reações não se fizeram esperar. O cardeal Spellman, de New York, lançou sobre pessoas imbecis a responsabilidade pelo ato de um papa ingênuo e manobrável: "Não acredito que o papa pretendesse convocar um concílio, mas que tenha sido forçado a isso por pessoas que entenderam mal as suas palavras" (PESCH, 2005, p. 43). O cardeal Lercaro, arcebispo de Bologna, um dos futuros líderes da maioria conciliar, peça-chave na condução dos debates sobre a reforma litúrgica e sobre os pobres, não escondeu sua surpresa:

Como pode (o papa) ousar convocar um concílio, depois de cem anos, e a três meses da sua eleição? O papa João é precipitado e impulsivo. A sua inexperiência e a sua falta de instrução conduzem-no a tal passo, a tal paradoxo. Um evento como esse sem dúvida arruinará a sua já frágil saúde e fará desmoronar o inteiro edifício da sua presumida virtude moral e teológica (PESCH, 2005, p. 43).

segundo critérios científicos (cf. BENIGNI, M.; ZANCHI, G. João XXIII. São Paulo: Paulus, 2000. p. 39-48); no início de seu ministério presbiteral, foi professor de História da Igreja no seminário maior de Bérgamo (cf. BENIGNI; ZANCHI, 2000, p. 85).

5 DMC, IV, p. 259. 
Nem mesmo Montini, arcebispo de Milão, amigo de longa data de João XXIII e que, no pontificado sucessivo, levará a termo o concílio, teve uma reação serena. Tendo sabido da notícia, ligou à noite para seu antigo amigo e confidente, o Pe. Júlio Bevilacqua, futuro cardeal: "Este santo velho menino parece não entender em que ninho de marimbondos está nos enfiando". Ao que Bevilacqua sabiamente respondeu: "Não se preocupe, padre Battista, deixe para lá, o Espírito ainda está acordado na Igreja!" (Cf. PESCH, 2005, p. 43). A um membro da Cúria que, algumas semanas depois, lembrou a João XXIII que o Vaticano I levara seis anos de preparação, sendo impossível, portanto, organizar o concílio antes de 1963, o papa respondeu com o costumeiro bom humor: "Ótimo! Então, iniciaremos o concílio em 1962!”. No fim dos anos 1960, acirraram-se as críticas à convocação do concílio e aos seus resultados. Circularam o mundo as palavras acerbas do cardeal Siri, um dos maiores expoentes do conservadorismo católico (AMERIO, 1985): "A Igreja precisará de 50 anos para refazer-se dos caminhos errados que João XXIII está percorrendo"6.

A reação entre os bispos foi lenta; a maioria estava por demais integrada no sistema eclesiástico vigente há séculos e reforçado depois do Vaticano I, sobretudo no pontificado de Pio XII, para se dar conta da dimensão e da relevância do que estava sendo proposto. O centralismo romano e a ideologia infalibilista talvez levassem muitos a pensar que, depois do concílio de Pio IX, bastaria ler os jornais no café da manhã para saber o que o papa determinara e executar fielmente suas deliberações. Em 1869, escrevera Joseph de Maistre (1753-1821): "Por que um concílio quando é suficiente o pelourinho [no sentido de quadro de avisos - n.d.a.]?" (DE MAISTRE, 1869, p. 276)7.

6 Outra versão: "A Igreja precisará de quarenta anos para refazer-se dos caminhos errados que João XXIII tem percorrido em quatro".

7 "O concílio universal tornou-se inútil e supérfluo para a Igreja católica" (HINSCHIUS, P. Kirchenrecht, t. III, Berlin: I. Guttentag, 1883. p. 630). "Os concílios não são necessários para a Igreja... A Igreja possui no primado do pontífice romano o órgão para o tempo ordinário e essencial da autoridade suprema, e esse órgão tem por si mesmo poder e graça para resolver todas as questões, baixar leis universais e responder a todos os problemas" (FORGET, J. Conciles. In: VACANT, A.; MANGEOT, E.; AMANN, É. Dictionnaire de théologie catholique: contenant l'exposé des doctrines de la théologie catholique, leurs preuves et leur histoire. T. neuvième. Deuxième partie, Mabillon - Marletta [Texte imprimé] / commencé sous la dir. de A. Vacant,... E. Mangenot,... continué sous celle de É. Amann,... ; avec le concours d'un grand nombre de collab. Paris: Librairie Letouzey et Ané, 1926-1927. 669), 
A reação dos cardeais presentes ao anúncio, de outros cardeais nas semanas seguintes e do Osservatore Romano mostra um aspecto característico do pontificado joanino:

a surdez de alguns setores da estrutura central da Igreja universal. Também este era um fato inédito, sobretudo depois do Vaticano I e depois da ênfase frequentemente posta sobre a estreita unidade entre cúria romana e papa. Da sua parte, Roncalli não era novato em matéria de dificuldade de entendimento com a cúria [em razão de seus 30 anos no serviço diplomático da Santa Sé - n.d.a.], mas a solidão institucional do seu serviço papal o surpreendeu e lhe desagradou, ainda que não o tenha feito desistir (ALBERIGO, 2000, p. 145).

Diferente foi a reação das pessoas e grupos empenhados, há décadas, nos movimentos de renovação social, laical, litúrgica, patrística, teológica, bíblica, missionária e ecumênica da Igreja católica, que João XXIII conhecia desde os primeiros passos de seu ministério presbiteral ao lado do bispo de Bérgamo, Giacomo Radini Tedeschi, líder do movimento católico italiano ${ }^{8}$. Esses ambientes acolheram com simpatia a decisão papal e, muito cedo, viram nela a feliz oportunidade de dar aos seus pleitos um cunho institucional e um impulso decisivo ${ }^{9}$. Os ambientes teológicos propriamente ditos, "que perceberam mais rapidamente a novidade do

apud ALBERIGO, G. Jean XXIII devant l'histoire. 2000, p. 202. Em 1923, o cardeal Billot afirmava que, com o dogma da infalibilidade papal, tinha-se colocado a palavra fim na época dos concílios, que, aliás, eram "caros, incômodos, cheios de problemas e perigos de todo tipo" (cf. Civiltà Cattolica (1969), II, p. 123 e 132). Uma plêiade de ponderações semelhantes sobre a desnecessidade de um concílio depois do Vaticano I encontram-se em CONGAR, Y. Le Concile de Vatican II: son Église, peuple de Dieu et corps du Christ. Paris: Beauchesne, 1984. p. 51-52. especialmente a nota 7 da p. 51.

8 'Com Radini, Roncalli faz experiência do 'pensar grande', vê a atuação de um pastor empenhado sem reservas, entra em contato com preocupações litúrgicas e ecumênicas pouco comuns na Itália e compartilha as primeiras fascinantes experiências de ação católica, entrando em contato com animados ambientes de 'feministas' católicas..." (ALBERIGO, G.; GIOVANNI XXIII,A. Profezia nella fedeltà. Brescia: Queriniana, 1978. p. 39). Suas atividades posteriores, com a juventude, com as missões, como diplomata na Bulgária (ortodoxia), na Turquia (islamismo) e, sobretudo, na França do pós-Guerra, colocá-lo-ão em contato não só com os fermentos de renovação que atravessavam a lgreja, mas também com problemas e processos muito mais amplos (cf. ALBERIG0, 1978, p. 49-57, 63-81, 101).

9 "No início do pontificado de João XXIII, havia um forte desejo de reforma, mas não havia nenhum difuso pedido de um novo concílio geral. 0 que preparou o Concílio Vaticano II não foi o pedido de um concílio, mas justamente essas ideias de reforma e as transformações que elas estavam lentamente produzindo" (SCHATZ, K. Storia dei concili: la chiesa nei suoi punti focali. Bologna: EDB, 1999. p. 249; cf. PESCH, 0.H. II Concilio Vaticano II: preistoria, svolgimento, risultati, storia post-conciliare. Brescia: Queriniana, 2005. p. 12-69).

Rev. Pistis Prax., Teol. Pastor., Curitiba, v. 4, n. 2, p. 357-393, jul./dez. 2012 
pontificado e do anúncio, estão empenhados em pôr as ideias em ordem, muitas vezes mal acreditando que se tenham efetivamente aberto espaços de renovação" (ALBERIGO, 2006, p. 30).

O impacto no movimento ecumênico foi imediato. "Que fosse o papa [depois de mais de um século de hostilidade católica ao movimento ecumênico - n.d.a. (CERETTI, 1992, p. 34-41)] a tomar a iniciativa da unidade entre as igrejas cristãs e a conceber este processo em termos de "cooperação" em vista de um "único rebanho" [não de um "único redil" n.d.a. (CERETTI, 1992, p. 34-41)], e não mais só de "retorno", era tão inesperado e quase inverossímil, a ponto de suscitar reações disparatadas e exigir um repensamento de toda a estratégia ecumênica" (ALBERIGO, 2006, p. 23 $)^{10}$. Nem tudo, evidentemente, são flores: teme-se que a iniciativa do papa esconda intenções de domínio e de absorção dos outros cristãos na Igreja romana; alerta-se contra um fácil e funesto irenismo; deixa-se claro que os problemas na caminhada ecumênica são sérios e devem ser enfrentados com sinceridade e realismo.

Surpreende, porém, que - numa sociedade cada vez mais secularizada em termos políticos e culturais - na própria opinião pública, a promoção de um "concílio" tenha suscitado atenção, interesse e até expectativas. Ainda que não entendesse bem do que se tratava, o grande público

tinha captado instintivamente, na iniciativa do pontífice ancião, um ato grávido de significado, havia lido um sinal de esperança, de confiança no futuro da renovação. Manifestou-se, além disso, uma vontade, talvez também ingênua, mas autêntica, de envolvimento e participação, que se sentia acolhida. Praticamente sem mediações, a iniciativa joanina chega a milhões de mulheres e homens e os convence do próprio alcance libertador e inovador (ALBERIGO, 2006, p. 24).

Nem as dimensões política e ideológica ficaram fora da avaliação daquele anúncio, viessem de um político católico como o futuro prefeito

10 Graças à menção dos "irmãos separados" no próprio anúncio do concílio e da insistência do papa na unidade dos cristãos, só aos poucos foi se dissipando, dentro e fora da Igreja, a confusão entre "concílio ecumênico", "concílio de união" e "concílio para a união" (cf. ALBERIGO, 1978, p. 159; PESCH, 0. H. II Concilio Vaticano II: preistoria, svolgimento, risultati, storia post-conciliare. Brescia: Queriniana, 2005. p. 48). 
de Florença Giorgio La Pira ou dos mais altos expoentes soviéticos em Moscou (ALBERIGO, 2006, p. 22-25).

\section{Que concílio?}

Entre o anúncio (25 de janeiro de 1959) e a inauguração (11 de outubro de 1962) transcorrerão dois anos e meio de muito trabalho.

Primeiro, era preciso caracterizar melhor o concílio anunciado. Os elementos contidos no anúncio diziam muito e, ao mesmo tempo, muito pouco. Depois da primeira reação global, parece que ninguém sabia bem o que dizer. Calam-se para não contrariar o papa que, em pouco tempo, tinha granjeado imensa simpatia? Calam-se na esperança de que o anúncio caia no vazio? Calam-se, porque desorientados diante da surpresa da perspectiva anunciada? Não sabem o que fazer da liberdade depois de séculos de rígido enquadramento institucional?

Aos poucos, porém, a intuição inicial vai ganhando contornos mais precisos. As primeiras luzes chegaram nos últimos dias de abril de 1959. A finalidade fundamental do concílio será incrementar o empenho dos cristãos, "dilatar os espaços da caridade... com clareza de pensamento e com grandeza de coração" (GIOVANNI XXIII, DMC I, 903). Será, claro, um concílio de bispos, mas com a participação de representantes das comunidades cristãs não católicas. Gozará de toda a liberdade e, por isso, terá poderes efetivamente deliberativos. Daí a necessidade de se distinguir clara e constantemente concílio e cúria. Uma maneira sutil - mas firme ${ }^{11}$ - de afirmar a independência do concilio! O concílio, por sua própria natureza, terá escopo, estrutura e vida próprios; a cúria responderá pela gestão ordinária da vida da Igreja, renunciando a qualquer veleidade de apoderar-se do concílio ou de manipulá-lo. Muito mais que isso: o papa de "transição" quer um concílio de "transição epocal", isto é, que

11 "0 concílio ecumênico tem uma sua própria estrutura e organização, que não pode ser confundida com a função ordinária e característica dos vários dicastérios ou congregações, que constituem a cúria romana... Portanto, distinções precisas: um é o governo ordinário da Igreja, de que se ocupa a cúria romana, e outro o concílio" (JOÃO XXIII. Preparazione, mete, speranze del concilio ecumenico, 5 de junho de 1960 apud ALBERIG0, 1978, p. 325). 
faça a igreja transitar da época pós-tridentina e, em certa medida, da plurissecular estação constantiniana a uma nova fase de testemunho e de anúncio, com uma recuperação dos elementos fortes e permanentes da tradição, julgados idôneos a alimentar e garantir a fidelidade evangélica de uma transição tão árdua (ALBERIGO, 2006, p. 26).

O concílio, repete o papa frequentemente, deverá ser um "novo Pentecostes”. Na oração pelo concílio, pede-se que o Espírito Santo renove "na nossa época os prodígios como de um novo Pentecostes" (JOÃO XXIII, DMC IV, 875). A obra do concílio - diz João XXIII, em 13 de novembro de 1960 - está inteiramente voltada à refontalização da Igreja: reconduzir "a Igreja de Jesus às linhas mais simples e mais puras do seu nascimento" (JOÃO XXIII, DMC IV, 5). "Mais do que de um ponto ou outro de doutrina ou de disciplina... trata-se de resgatar o valor e o esplendor da substância do pensar e do viver humano e cristão..." (JOÃO XXIII, DMC III, 18). Enfim, resulta de diversos textos o caráter pastoral do Vaticano II: “por sua própria natureza, pastoral” (JOÃO XXIII, DMC V, 516).

\section{A fase antepreparatória: consulta ampla e aberta}

Significativamente, foi na solenidade de Pentecostes de 1959 que, de novo de forma inesperada, o papa tornou pública a decisão de instituir a Comissão antepreparatória. A sua composição, porém, parecia em nítida contradição com o que o próprio papa dispusera sobre a independência do concílio. Seguia os mesmos moldes da preparação do Vaticano I e era monopolizada pela cúria: uma pequena comissão de dez membros, quase só italianos e romanos, representando todas as congregações da cúria, presidida pelo cardeal Domenico Tardini, secretário de Estado, e secretariada por Pericle Felici, latinista, canonista, assessor da Sagrada Rota. Sua tarefa era recolher material para a "preparação próxima" dos trabalhos conciliares, delinear os temas a serem tratados no concílio e formular propostas para a composição dos órgãos responsáveis pela preparação propriamente dita.

A comissão pensou em preparar um questionário, definiu alguns "temas prováveis" e cogitou estabelecer uma ligação entre os temas e as 
respectivas congregações romanas. As reações críticas não se fizeram esperar: como se explica que a preparação de um concílio universal de bispos seja confiada a um reduzidíssimo grupo de altos burocratas que, em sua maioria, nem bispos são?

Também aí, porém, se manifestavam o temperamento ${ }^{12}$ e a sabedoria do historiador, do diplomata e do homem de igreja condensados em João XXIII. A organização e o processo continham algumas novidades que se mostraram decisivas: a secretaria de Estado - mais próxima e mais afinada com ele - e não a "Suprema", o Santo Ofício (antiga Inquisição, atual Congregação da Doutrina da Fé) era responsável pela condução desta fase; a escolha de membros da cúria era um gesto de confiança inspirado no desejo e na esperança de obter a lealdade da cúria em relação ao concílio ${ }^{13}$; a consulta devia ser a mais ampla possível e não limitada a alguns, como no Vaticano ${ }^{14}$; o papa descartou a hipótese do questionário, convidando, ao invés, cada um a indicar, com total liberdade, os assuntos que o concílio deveria tratar ${ }^{15}$. Com o novo papa, Roma não mandava, mas pedia sugestões ${ }^{16}$.

12 "Sou grato ao Senhor pelo temperamento que me deu... Sinto-me em obediência em tudo e constato que esta atitude, in magnis et in minimis, confere à minha pequenez tanta força de audaz simplicidade que, sendo toda evangélica, solicita e obtém respeito geral e é motivo de edificação para muitos... Na mansidão e na humildade do coração, está a boa graça do receber, do falar, do tratar, a paciência do suportar, do compadecer, do calar-se, e do encorajar..." (JOÃO XXIII. Diário da Alma. 29 de novembro - 10 de dezembro de 1959).

${ }^{13} 0$ juízo do secretário particular é benévolo em relação à cúria: "Ao lado de compreensíveis titubeios, a colaboração - assim creio - foi leal, mais do que se queira admitir". (CAPOVILLA, L. F. Ricordi dal concilio: siamo appena all'aurora. Brescia: La Scuola, 2011. p. 50).

${ }^{14}$ Enquanto, antes do Vaticano I, foram consultados só 47 bispos, agora a consulta inclui todos os bispos, os superiores das ordens e congregações religiosas, as faculdades eclesiásticas. Entre 1959 e 1960, sobre um total de 2800 pessoas interpeladas, 2150 responderam. Em geral, porém, as indicações eram repetitivas, pouco inovadoras e marginais (cf. SCHATZ, 1999, p. 260).

15 "Ele quer fazer-se instrumento do Espírito e por isso decide não impor ao concílio e à lgreja um programa rígido; propõe-se, ao contrário, a suscitar uma atitude de escuta e de disponibilidade; 0 restante iria clareando-se à medida que as coisas caminhassem" (ALBERIG0, 2000, p. 146).

${ }^{16}$ As sugestões, analisadas e classificadas entre o início de setembro de 1959 e o fim de janeiro de 1960 , deram origem a um índice, com 18 divisões temáticas, intitulado "Síntese analítica dos conselhos e sugestões dados pelos bispos e prelados”, que ocupa mais de 1.500 páginas. Foram elaboradas, em seguida, sínteses por grandes áreas geográficas, que foram lidas pessoalmente por João XXIII entre 13 de fevereiro e $1^{\circ}$ de abril. 0 trabalho da Comissão antepreparatória terminou com a redação de uma breve "Síntese final 
Quando, no dia 14 de julho de 1959, o papa comunicou ao secretário de Estado, cardeal Tardini, o nome do futuro concílio - Vaticano II - ficou claro que não seria uma retomada do Vaticano I, que não pudera ser concluído por causa da guerra franco-prussiana e à tomada de Roma, em setembro 1870, pelas tropas italianas comandadas pelo general Cadorna. Seria um concílio novo, com agenda aberta, em outro clima: uma página branca a ser escrita pelos bispos de uma igreja não só universal, mas agora, finalmente, também mundial (Weltkirche).

\section{A fase preparatória: 0 trabalho das comissões pré-conciliares}

A preparação propriamente dita foi confiada, no dia 5 de junho de 1960, a uma comissão central e a dez comissões (grupos de trabalho) para as diversas áreas temáticas. As comissões continuaram sendo presididas pelos cardeais que presidiam as Congregações da cúria. A novidade mais vistosa, porém, foi constituída pela inclusão, entre as comissões, de uma do Apostolado dos leigos, sob a presidência do cardeal F. Cento, e outra, do recém-criado Secretariado para a unidade dos cristãos, presidida pelo cardeal Agostinho Bea, ex-reitor do Pontifício Instituto Bíblico. Aos poucos, porém, não sem dificuldade e a partir de nomeações sucessivas, a composição dessa estrutura tradicional foi sendo retirada do completo monopólio da cúria e dos ambientes romanos ${ }^{17}$. De um lado, foi internacionalizada pelo ingresso de bispos do mundo inteiro; de outro, teólogos de diversas tendências passaram a participar dos trabalhos preparatórios, inclusive alguns que, sob Pio XII, tinham sido alvo de sanções romanas.

dos conselhos e sugestões dos excelentíssimos bispos e prelados de todo o mundo para o futuro concílio ecumênico". A partir desses elementos, no mês de julho, o secretariado da Comissão prepara as "Questões postas às Comissões preparatórias do concílio": 54 temas divididos em 11 grupos.

${ }^{17}$ A avaliação de De Mattei é amarga, porém objetiva: "Ā errônea convicção dos cardeais Ottaviani e Ruffini de poder controlar a forte personalidade de João XXIII, seguiu-se aquela [errônea convicção - n.d.a.] de poder manter sob o controle da Cúria romana o concílio e achar que ele teria reafirmado o ensinamento tradicional da Igreja contra os erros que serpenteavam" (DE DE MATTEI, R. I/ Concílio Vaticano II: uma storia mai scritta. Torino: Lindau, 2011. p. 121). 
Em pouco mais de dois anos, a partir das "Quaestiones" de 1960, as comissões preparatórias elaboraram cerca de 70 projetos. De modo geral, repetiam os ensinamentos doutrinais e disciplinares dos últimos papas, sobretudo de Pio XII, com a convicção de que o concílio - que se acreditava e se desejava nos ambientes conservadores fosse breve! - os haveria de referendar ${ }^{18}$. Essa fase foi encerrada pelo motu próprio "Concilium", por meio do qual João XXIII, no dia 2 de fevereiro de 1962, estabelecia o dia 11 de outubro para a abertura da assembleia conciliar.

Algumas coisas foram ficando claras: 1) o Vaticano II não seria um "concílio de união" entre as igrejas divididas ${ }^{19}$, mas devia marcar uma virada na disponibilidade católica de se envolver profundamente no processo ecumênico, sobretudo a partir do "aggiornamento" da Igreja católica; 2) o concílio teria a marca da "pastoralidade" ${ }^{20}$, como não se cansava de repetir João XXIII: em vez da clássica dupla "doutrina-disciplina”, a assembleia conciliar deveria prospectar - neste momento histórico novo e particularmente propício - uma consideração geral sobre as exigências da vida da Igreja e das suas relações com a sociedade, consideração evangelicamente inspirada na caridade, para que transpareça em tudo o Cristo bom Pastor ${ }^{21}$; 3) os padres

${ }^{18}$ Como à época do Vaticano I, quando, ironicamente, o geral dos redentoristas podia escrever a Dechamps, arcebispo de Malines: "Em Roma, tudo está tão bem preparado que os Padres não terão senão que votar" (BECQUÉ, M. Le Cardinal Dechamps, t. II, p. 157 apud THILS, G. L'ecclesiologia del Concilio Vaticano I: preparazione, risultati, problemi, dans L'ecclesiologia dal Vaticano I al Vaticano II. Milão: La Scuola, 1972. p. 9).

${ }^{19}$ Concilio de "união" teria sido, por exemplo, a seu modo, o Lionense II (1274), mas seus resultados foram efêmeros. A união com os gregos foi efêmera, seja porque respondia mais a interesses políticos que religiosos, seja porque 0 episcopado grego, terminando o concílio, não reconheceu os decretos conciliares, seja porque não se quis enfrentar a profundidade teológica das questões, sobretudo a vistosa diferença eclesiológica entre Ocidente e Oriente (cf. ALBERIGO, G. (Org.). História dos Concílios Ecumênicos. São Paulo: Paulus, 1995. p. 210).

20 "Pastoral" exprime "a dimensão central da eclesiologia de Roncalli, que quer qualificar o concílio que ele convocou de 'concílio pastoral'. 'Pastoral' e os vocábulos da mesma raiz ocupam um lugar muito importante no vocabulário roncalliano. Eles voltam constantemente ao longo dos numerosíssimos escritos que escalonam sua existência, com quase duas mil ocorrências, de acordo com a concordância verbal estabelecida por A. Melloni no Istituto per le Scienze Religiose de Bologna." (ALBERIGO, 1989, p. 206). "A 'pastoralidade' atribuída ao novo concílio pelo papa como característica dominante, o que queria dizer? Ela foi por muito tempo banalizada e entendida no sentido de colocar o concílio num nível não teológico, puramente operativo... Só na imediata proximidade do concílio abriu estrada a acepção forte da 'pastoralidade' como subordinação de todo outro aspecto da vida da igreja à imagem exigente do Cristo como 'bom pastor'” (ALBERIGO, G. (Org.). Breve storia del concilio Vaticano II (1959-1965). Bologna: II Mulino, 2006. p. 38).

${ }^{21}$ Na homilia por ocasião da coroação, João XXIII encontra na Escritura e na História sua concepção da pastoralidade. 
conciliares seriam os protagonistas do concílio, atuando com plena liberdade e saindo da passividade a que estavam submetidos ${ }^{22}$.

Entrementes, no dia 15 de maio de 1961, por ocasião do $70^{\circ}$ aniversário da Rerum novarum, o papa publicou a encíclica Mater et magistra, que, mesmo retomando afirmações habituais do ensinamento social da Igreja, introduzia importantes novidades, sobretudo se confrontadas com a impostação tradicionalista que, àquela altura, sobre os mesmos temas, davam as comissões pré-conciliares. A Mater et magistra, de fato, abandona o habitual método dedutivo; usa sem reservas o termo "socialização", vendo-a sobretudo como um fenômeno de massa; depura de tons moralísticos os temas já tratados em anteriores documentos, como propriedade, trabalho, empresa, etc.

No Natal do mesmo ano - quase três depois do anúncio - João XXIII, por meio da constituição apostólica Humani salutis, convocou solenemente o concílio. Neste importante texto, o papa enquadra o significado do

$\mathrm{Na}$ Escritura: "Há quem espere no pontífice o homem de estado, o diplomata, o cientista, o organizador da vida coletiva [...] o novo papa... é, como o filho de Jacó, que, encontrando-se com seus irmãos de humana desventura, Ihes revela a ternura do seu coração e, prorrompendo em pranto, diz: ‘Sou... o vosso irmão José'. 0 novo pontífice... realiza, antes de tudo em si mesmo aquela esplêndida imagem do Bom Pastor [...] Todo pontificado toma a fisionomia própria do semblante daquele que o personifica e representa [...] 0 ensinamento divino e a sua grande escola são resumidos na palavra dele: 'Aprendei de mim que sou manso e humilde de coração'. A grande lei, portanto, é a mansidão e a humildade" (Homilia Joannis PP. XXIII in die coronationis habita, 4.11.1958). A inspiração histórica está em São Carlos Borromeu, cuja festa ocorre justamente no dia 4 de novembro, data escolhida para a coroação. "Função pastoral, reforma e concílio são as três palavras-chave do pontificado do papa João, que emergem claramente já no seu discurso inaugural” (BENIGNI; ZANCHI, 2000, p. 232).

${ }^{22}$ A primeira dramática afirmação da liberdade do concílio será dada no dia 13 de outubro, primeiro dia dos trabalhos conciliares, quando se deviam escolher os membros eletivos das comissões conciliares, que, por uma manobra da cúria, podiam acabar sendo basicamente os mesmos das respectivas comissões preparatórias. 0 cardeal Tisserant presidia a sessão; no início da votação, o cardeal Liénart, de Lille, pediu a palavra; Tisserant negou-Ihe; Liénart tomou o microfone e, depois de dizer "Je la prends tout de même", propôs uma moção de adiamento, argumentando que os padres conciliares se conheciam muito pouco e que era necessário mais tempo para tomar decisões tão comprometedoras; ele e o cardeal Frings, de Colônia, sugeriram uma consulta prévia entre os membros das diversas circunscrições eclesiásticas, o que permitiria um maior conhecimento dos candidatos. Aplauso retumbante! Foi neste momento, comenta 0 bispo norteamericano Robert J. Dwyer, que "nos demos conta de ser um concílio e não uma classe de alunos de escola primária, reunida ao som de tambores!" (cf. PESCH, 2005, p. 83). A sessão foi suspensa; reuniram-se os dez presidentes; consultado, João XXIII apoiou a ideia do adiamento. Nos dias seguintes, as conferências episcopais se reuniram e prepararam listas eleitorais, que foram votadas na sessão do dia 16 de outubro, instituindo, assim, comissões internacionalizadas.

Rev. Pistis Prax., Teol. Pastor., Curitiba, v. 4, n. 2, p. 357-393, jul./dez. 2012 
concílio no seu momento histórico, com suas oportunidades e dificuldades. Para ele, as mudanças pelas quais o mundo moderno está passando são tão grandes que o colocam no limiar de uma nova era: "A Igreja assiste, hoje, a grave crise da sociedade. Enquanto para a humanidade desponta uma era nova, obrigações de uma gravidade e amplitude imensas pesam sobre a Igreja, como nas épocas mais trágicas da sua história" (JOÃO XXIII, 1961, 3). Sua visão da modernidade não é que seja muito diferente da dos bispos e papas depois da Revolução Francesa. O que diferencia o papa do concílio, porém, deles, é o espírito de fé e confiança em Cristo e no Espírito com que se coloca diante desta situação. Daí a necessidade de a Igreja sentir "o ritmo do tempo" e distinguir os "sinais dos tempos":

Estas dolorosas averiguações conclamam ao dever da vigilância e despertam o senso da responsabilidade. Almas sem confiança veem apenas trevas tomando conta da face da terra. Nós, porém, preferimos rearmar toda a nossa confiança em nosso Salvador, que não se afastou do mundo, por ele remido. Antes, mesmo, apropriando-nos da recomendação de Jesus, de saber distinguir "os sinais do tempo" (Mt 16,3), parece-nos vislumbrar, no meio de tanta treva, não poucos indícios que dão sólida esperança de tempos melhores para a Igreja e a humanidade (JOÃO XXIII, 1961, 4).

A convocação do concílio enquadra-se nessa perspectiva: "Diante deste duplo espetáculo - um mundo que revela um grave estado de indigência espiritual e a Igreja de Cristo, tão vibrante de vitalidade - nós, desde quando acedemos ao supremo pontificado, não obstante nossa indignidade e por um desígnio da Providência, sentimos logo o urgente dever de conclamar os nossos filhos para dar à Igreja a possibilidade de contribuir mais eficazmente na solução dos problemas da idade moderna" (JOÃO XXIII, 1961, p. 6).

Por isso, o concílio não deve se concentrar "em um ou mais pontos da doutrina católica", mas em abrir-se "a uma verdadeira epifania, a uma revelação que não se limita a este ou aquele tema, mas toca todas as coisas, todo o bem dado ao cristianismo..." ${ }^{23}$

Faltando um mês para a solene abertura, a partir de uma radiomensagem, João XXIII manifestou ainda algumas convicções em relação

${ }^{23} \mathrm{ADP}$ I, 44. 
ao grande evento: 1) o concílio aconteceria "na hora certa", ou seja, numa daquelas "horas históricas da Igreja", o que propiciaria um seu novo deslanchar; 2) a renovação do encontro do rosto de Jesus ressuscitado, como continuação, melhor ainda, "retomada mais enérgica da resposta do mundo inteiro, do mundo moderno ao testamento do Senhor"; 3) a unidade que existiu por séculos entre todos os cristãos interpela todos aqueles que "não são insensíveis ao sopro novo que o projeto do concílio desperta" em direção ao "fraterno congraçamento" dos cristãos na única antiga comunhão; 4) "diante dos países subdesenvolvidos, a Igreja se apresenta como ela é, e quer ser, como a Igreja de todos, e particularmente dos pobres" (JOÃO XXIII, 1962).

Durante o verão europeu, foram enviados para análise dos bispos sete "esquemas" (sobre as fontes da revelação, o depósito da fé, a ordem moral, a liturgia, a família, as comunicações sociais e a unidade da Igreja). Muitas das reações apontavam para a distância entre as perspectivas abertas pelo papa e a linha dos projetos. O esquema da liturgia era o único a obter um positivo consenso ${ }^{24}$.

No período imediatamente anterior ao concílio, temia-se que o velho espírito da fase da preparação sufocasse o concílio sonhado por João XXIII. Os bispos seriam capazes de reagir aos "esquemas" preparados em Roma? Os cardeais Suenens e Léger procuraram o papa para manifestar com toda a clareza esta preocupação.

Para o bom funcionamento do concílio - que viria a reunir cerca de 2.500 bispos, mais de 500 teólogos e representantes das igrejas e comunidades não católicas - era necessário estabelecer procedimentos que permitissem a participação de todos e a transparência das votações. Para tanto, foi elaborado o Regulamento da celebração do concílio, aprovado em 6 de

\footnotetext{
${ }^{24}$ Veja-se a interpretação que fará De Mattei desse esquema: "O balanço da Aliança centro-europeia era mais que satisfatório: remanejamento das dez Comissões conciliares e eliminação de todo o trabalho preparatório, pelo que dos esquemas predispostos era destinado a sobreviver só o De liturgia, aquele que agradava menos a João XXIII, mas o único que satisfazia os progressistas, definido pelo dominicano Edward SchillebeeckX 'uma verdadeira obra-prima'. Os holandeses insistiram para que o esquema, que figurava como o quinto na ordem dos trabalhos, fosse o primeiro a ser discutido. Tratou-se, como sublinha Wiltgen, de uma nova vitória do fronte centro-europeu. 0 esquema era, de fato, o fruto do trabalho da única comissão dominada pelos progressistas, a litúrgica, formada sobretudo por expoentes do movimento litúrgico centro-europeu" (DE MATTEI, 2011, p. 238).
}

Rev. Pistis Prax., Teol. Pastor., Curitiba, v. 4, n. 2, p. 357-393, jul./dez. 2012 
agosto de 1962, publicado em 5 de setembro, e que, de fato, só pôde chegar ao conhecimento dos bispos às vésperas do evento. O referencial era o regulamento do Vaticano I (que, por sua vez, tinha por base o sucinto regulamento do Lateranense $V$ ), do qual, entretanto, participara, como se sabe, um número bem menor de bispos, além de ter sido fortemente condicionado pela atuação de Pio IX ${ }^{25}$. À medida que os trabalhos conciliares foram se desenvolvendo, percebeu-se a necessidade de modificar as regras previstas, no que também João XXIII teve, em várias ocasiões, uma participação sábia e decisiva. Na verdade, ele, embora tivesse a responsabilidade final pela organização da preparação e pela alta direção dos trabalhos conciliares propriamente ditos, não tomou nenhuma decisão importante para orientar as coisas na direção querida por ele, mas cobrou, na hora oportuna, os responsáveis pela engenharia, agenda e andamento do concílio. Em relação à língua a ser usada nas sessões plenárias, apesar da Veterum sapientia ${ }^{26}$, decidiu que o latim seria a língua oficial, mas, quando necessário, haveria espaço também para as outras línguas ${ }^{27}$. O Regulamento desatendeu a

${ }^{25}$ Da sessão de abertura do Vaticano I participaram 744 bispos; na votação da Pastor aeternus, cerca de 50 bispos se ausentaram da sessão, 88 votaram contra e 65 "placet iuxta modum", sobre um total de 601 votantes. Quanto à "liberdade” do concílio, leia-se, por exemplo, AUBERT, R. Vatican I. Paris: Éditions de l'Orante, 1964. p. 243.

${ }^{26}$ A publicação da Veterum sapientia (22 de fevereiro de 1962) foi motivo de desconcerto e consternação. Trata-se de uma confusa collage de posições disparatadas mantidas unidas pela ideia do latim como língua oficial que "os ambientes mais fechados da cúria conseguiram obter do papa" (MELLONI, A. Tensioni e timori nella preparazione del Vaticano II. La "Veterum sapientia" di Giovanni XXIII (22 febbraio 1962). Cristianesimo nella Storia, v. 11, p. 275-307, 1990). Isto não impediu que, em concílio, os padres discutissem com toda a liberdade sobre a adoção do vernáculo na liturgia. A respeito - e também diante de outras atitudes do papa - fala-se do "paradoxo João XXIII" (cf. PESCH, 2005, p. 59-61.74ss. Parece que, além de convicções pessoais, jogassem um peso também "os próprios princípios metodológicos; antes de tudo, o de valorizar aquilo que une e, não menos, o da máxima condescendência possível. Ver tudo, relevar muito e corrigir pouco, um adágio que the era caro se tornava sempre mais atual e o seguia de bom grado. Ao mesmo tempo, porém, julgava não dever abrir mão do projeto anunciado; as resistências, no máximo, o estimulavam a precisá-lo melhor" (ALBERIG0, 2000, p. 145). "A propósito desta consistente dimensão do pontificado, parece inadequada uma explicação de tipo apologético, que quisesse creditar todos os atos de abertura e desenvolvimento acolhidos com simpatia ao papa Roncalli, e todos os outros, à cúria romana. Mediante estudos rigorosos, será necessário buscar explicações mais 'internas' e provavelmente menos maniqueias. Já se refazendo à distinção entre aquilo que Roncalli julgava substancial ou acessório se dispõe de um critério importante, como também aquele - a este conexo - da recorrente relutância do aparato curial a adequar-se a determinadas orientações do papa" (ALBERIGO, 1978, p. 24).

${ }^{27}$ Cf. ADP I, 95. Na segunda sessão do concílio, mais exatamente no dia 13 de outubro de 1963, porém, começou a funcionar, na basílica de São Pedro, um serviço de tradução simultânea em cinco línguas (cf. DE MATTEI, 2011, p. 241). 
essa determinação, permitindo o uso de outras línguas só nas comissões. Contrariando, porém, o Regulamento, o patriarca Maximos IV Saigh usava o francês nas congregações gerais (sessões plenárias).

Alguns fatos importantes marcaram essa última etapa da preparação: 1) o convite de "observadores" das igrejas cristãs não católicas; 2) as iniciativas visando à participação dos bispos católicos impedidos de sair de seus países (poloneses, húngaros, romenos, búlgaros, bálticos, russos) pelo regime comunista, o que gradualmente dará início à chamada Ostpolitik; 3) o simbolismo do fracasso do sínodo romano, anunciado na campanha do concílio em 25 de janeiro de 1959; 4) os encontros informais entre os futuros padres conciliares.

A presença dos "observadores", que tiveram participação ativa nos trabalhos das comissões, não tem precedentes na história da Igreja ${ }^{28}$.

A autorização para que os bispos dos países europeus sob regime comunista pudessem vir a Roma foi obtida a partir de um trabalho muito bem articulado, uma vez que não havia relações diplomáticas entre o Vaticano e esses países e o clima, de um lado e do outro, era geralmente pautado pela intransigência e pela hostilidade. (ALBERIGO, 2006, p. 156)

O sínodo romano foi um vistoso fracasso, sintoma de uma crise profunda em Roma, centro da cristandade, "caput mundi", como se costumava dizer: "A diocese não estava preparada e vivia num estado secular de desagregação; boa parte da estrutura do Vicariato não sintonizou com os propósitos do papa; o próprio instrumento sinodal devia passar por adequações" (ALBERIGO, 2006, p. 152). O que não tira, contudo, nem o mérito nem os benefícios da iniciativa papal: foi o primeiro sínodo romano em toda a idade moderna; trouxe à consciência eclesial o caráter diocesano da Igreja particular de Roma, removido há séculos; muito poucos compreenderam a consciência de João XXIII, frequentemente expressa, de ser bispo de Roma e de caber a ele, a partir daí, como papa, ser ministro da unidade eclesial universal. O papa, porém, com o garbo que lhe era peculiar, não deixou de manifestar sua insatisfação com os resultados:

${ }^{28}$ Muitos séculos antes dos concílios de Lião e Florença, a igreja ortodoxa de língua grega interviera enquanto tal; do concílio de Trento, participaram inicialmente os protestantes, que logo se ausentaram, dada a profundidade e extensão da separação com os católicos; no Vaticano I, os ortodoxos orientais e os protestantes ignoraram o convite desastrado de Pio IX (cf. AUBERT, 1964, p. 48). 
"pudemos, com a ajuda do Senhor, realizar, certamente, um opus bonum, embora, em algumas coisas, não um opus perfectum ${ }^{29}$ ". Talvez temesse que o mau desempenho do sínodo respingasse, como queriam alguns, no projetado concílio ecumênico, cuja preparação continuava.

Problemas logísticos muito concretos, sobretudo no início do concílio - alojamento, alimentação, transporte e outros - acabaram por propiciar aos bispos encontros inicialmente informais, mais tarde, progressivamente formalizados, que permitiram um crescimento afetivo e efetivo da comunhão entre eles ${ }^{30}$.

A fase preparatória concluiu-se com dois gestos de grande poder evocativo - a peregrinação a Loreto e a Assis, no dia 4 de outubro de 1962 que o papa quis realizar pelo "feliz desenvolvimento da grande assembleia ecumênica". Loreto evoca, na verdade, a encarnação do Verbo; Assis, o papel dos "pequenos" na Igreja e a paz na terra ${ }^{31}$. Dois aspectos caros ao papa Roncalli.

\section{A solene abertura: a perene vitalidade do Evangelho numa mudança de época}

No dia 11 de outubro de 1962, João XXIII inaugurou solenemente o Concílio Ecumênico Vaticano II. No contexto da celebração eucarística, pronunciou o discurso Gaudet mater Ecclesia, que foi, na opinião do historiador dos concílios Giuseppe Alberigo, "o ato mais relevante do pontificado joanino e provavelmente um dos mais desafiadores e significativos da Igreja católica na idade contemporânea" (ALBERIGO, 2006, p. 43). Redigido pessoalmente, como o comprovam os manuscritos e inúmeras

${ }^{29}$ DMC III, 38.

${ }^{30}$ No caso dos bispos brasileiros, o fato de terem a Domus Mariae como "local de moradia e trabalho", 0 Pio Brasileiro como "ponto de apoio" e uma série de "redes e relações" (CNBB, CELAM, redes por famílias religiosas, nacionalidade e língua, redes dos bispos ligados aos movimentos leigos, etc.) e de se terem organizado, na Domus Mariae, conferências com os maiores expoentes da teologia e do episcopado mundial atuantes no concílio, tudo isso resultou num ganho intelectual, afetivo e pastoral que impulsionou e facilitou enormemente, no período pós-conciliar, o exercício da colegialidade episcopal (cf. BEOZZO, J. O. A Igreja do Brasil no Concílio Vaticano II (1959-1965). São Paulo: Paulinas, 2005. p. 163-219).

${ }^{31}$ Cf. DMC IV, 558 e 565. 
testemunhas ${ }^{32}$, nele, o papa exprimia as convicções mais profundas que o levaram a convocar o concílio.

A primeira parte trata, por um lado, da natureza, da convocação e da preparação do concílio; pelo outro, de Cristo, da Igreja e da história. O Vaticano II situa-se diante dos "desvios, exigências e oportunidades da idade moderna"; é chamado a ser "celebração solene da união de Cristo e da sua Igreja"33, ou seja, ocasião para "um conhecimento mais amplo e objetivo" das possibilidades da Igreja a serviço da sociedade humana e do seu futuro, portanto, com uma atitude de acolhida, simpatia e confiança. O papa espera que, graças ao concílio, a Igreja se enriqueça espiritualmente e olhe corajosamente para o futuro, "mediante oportunos aggiornamenti". Por isso, é necessário discernir os "sinais dos tempos", superando "as insinuações daquelas pessoas, ardentes de zelo, sem dúvida, mas não dotadas de superabundante senso de discrição e de medida, que não veem nos tempos modernos senão prevaricação e ruína e vão dizendo que a nossa época, comparada com as passadas, foi piorando"; muito ao contrário, afirma o papa, sinto-me no dever de "discordar desses profetas de desventura, que anunciam eventos sempre infaustos, como se o fim do mundo fosse iminente". O papa diz-se convicto de que a humanidade inteira está se encaminhando para um novo ciclo histórico que traz em seu seio um significado de salvação "inesperado" e "imprevisto".

A segunda parte da alocução Gaudet mater Ecclesia aborda alguns pontos essenciais: a relação dinâmica entre reino de Deus e sociedade, a oportunidade de uma reformulação dos dados essenciais da fé, a opção por um estilo de misericórdia em vez da severidade ${ }^{34}$, compromisso com a busca da unidade entre os cristãos. $O$ papa não pretende estabelecer a agenda dos trabalhos conciliares; a ele interessa sublinhar o espírito do

320 texto crítico, reconstruído com base nos manuscritos originais, encontra-se em ALBERIGO, G.; MELLONI, A. Fede, tradizione, profezia: studi su Giovanni 23 e sul Vaticano 2. Brescia: Morcelliana, 1984. p. 185-283.

${ }^{33} 0$ concílio, aqui, é visto mais como uma celebração privilegiada do mistério da Igreja do que como puro órgão de magistério e/ou de governo (cf. DOSSETTI, G. II Vaticano II: frammenti di una riflessione. Bologna: EDB, 1996. p. 191-219).

34 "... a esposa de Cristo prefere usar mais o remédio da misericórdia do que o da severidade. Julga satisfazer melhor às necessidades de hoje, mostrando a validez da sua doutrina do que renovando condenações" (Gaudet mater Ecclesia VII, 2). 
concílio para dar uma contribuição à transição da Igreja para uma nova época histórica. Ele deixa claro que o trabalho do concílio não é

a discussão de um ou outro tema da doutrina fundamental da Igreja, repetindo e proclamando o ensino dos Padres e dos Teólogos antigos e modernos... Para isto, não havia necessidade de um Concílio... O espírito cristão, católico e apostólico do mundo inteiro espera um salto à frente ("un balzo innanzi") em direção a uma penetração doutrinal e uma formação das consciências em correspondência mais perfeita à fidelidade à autêntica doutrina, também esta, porém, estudada e exposta por meio das formas da pesquisa e da formulação literária do pensamento moderno. Uma é a substância da antiga doutrina do depositum fidei, e outra é a formulação do seu revestimento: e é isso que se deve - com paciência, se necessário - ter em grande conta, medindo tudo nas formas e proporções de um magistério de caráter prevalentemente pastoral ${ }^{35}$.

Este é, segundo João XXIII, o elemento central ("punctum saliens") do Vaticano II, para que a Igreja possa ir "ao encontro das necessidades de hoje, mostrando a validade da doutrina e não recorrendo a condenações". O concílio coloca-se, enfim, não só na perspectiva da unidade de todos os cristãos, mas de toda a humanidade. Contempla-se o "grande mistério da unidade" numa tríplice irradiação: dos católicos entre si, de todos os cristãos, e das pessoas de todas as religiões.

\section{A alocução inaugural conclui com uma citação de São Cipriano:}

A Igreja, aureolada de luz divina, envia os seus raios ao mundo inteiro; é, porém, luz única, que por toda a parte se difunde sem que fique repartida a unidade do corpo. Estende os seus ramos sobre toda a terra pela sua fecundidade, difunde sempre mais e mais os seus regatos: contudo, uma

${ }^{35}$ Tradução minha do texto italiano distribuído pela Sala de Imprensa do Concílio; as palavras em itálico também são minhas. 0 texto, proposto no dia 23 de setembro de 1964 à assembleia para a revisão, refere-se ainda à versão latina (João XXIII escreveu de próprio punho em italiano), corrigida pela Cúria, do discurso de João XXIII. A versão latina não corresponde ao texto original, pois diz: um é "o próprio depósito da fé, ou seja, as verdades contínuas na nossa venerável doutrina", e outra "a forma sob a qual estas verdades [plural] são enunciadas". 0 texto original sublinha simplesmente "a diferença fundamental ["uma é... outra é"] entre o depósito da fé, tomado aqui como um todo - sem referências a uma pluralidade interna que depende já da expressão - e a forma histórica que toma nesta ou noutra época" (THEOBALD, C. Nodi ermeneutici dei dibattiti sulla storia del Vaticano II apud MELLONI, A.; RUGGIERI, G. (Org.). Chi ha paura del Vaticano II? Roma: Carocci, 2009. p. 67. 
só é a cabeça, única é a origem, uma é a mãe copiosamente fecunda; por ela fomos dados à luz, alimentamo-nos com o seu leite, vivemos do seu espírito (De Catholicae Ecclesiae unitate, 5 apud DISCURSO... 1962).

A alocução causou impacto, embora seu alcance - que escapou à maioria - só lentamente foi sendo percebido e explorado ${ }^{36}$.

\section{Os primeiros passos de uma longa e difícil caminhada}

Era necessário que o concílio, desde o início, falasse ao mundo que as decisões do concílio fossem abertas por uma ampla declaração, na qual, com o estilo do Evangelho, dentro das perspectivas proféticas do Antigo Testamento, fosse proclamado o desígnio da salvação... Declaração dirigida a uma humanidade em que grandeza e miséria são, entre erros e falências, uma aspiração à luz do Evangelho... Declaração que proclame a unidade fraterna dos homens, acima das fronteiras, raças, regimes, na recusa de soluções violentas, no amor e na paz, teste do Reino de Deus ${ }^{37}$.

Uma breve mensagem, neste sentido, enfatizando a disposição da Igreja em servir, sua solidariedade com as angústias que afligem sobretudo

${ }^{36}$ Não se pode omitir um gesto, aparentemente pequeno, do papa, na noite do dia 11 de outubro. 0 dia devia concluir com uma manifestação com tochas ("fiaccolata") da Ação Católica, na Praça São Pedro. 0 secretário particular aborda o papa em seu escritório: "Santidade, não se apresente à janela, não fale, mas olhe por meio da cortina que espetáculo, a praça São Pedro está cheia de tochas, parece incendiada!" De fato, foi à janela, dizendo-me pouco depois: “Coloque-me a estola!” E iniciou aquela conversa, convidando a multidão a olhar a lua..." (CAPOVILLA, 2011, p. 73). "Caros filhos, escuto as vossas vozes. A minha é uma só, mas recolhe todas as vozes do mundo; e aqui, de fato, o mundo é representado. Dir-se-ia que até a lua se apressou esta noite... Observai-a no alto, a olhar este espetáculo... Estamos fechando um grande dia de paz... Se perguntasse, se pudesse perguntar a cada um: de que parte vindes? Os filhos de Roma, que estão aqui especialmente representados, responderiam: ah, nós somos os filhos mais próximos, e vós sois o nosso bispo... A minha pessoa não conta nada: é um irmão que vos fala, um irmão tornado pai por vontade de Nosso Senhor... Continuemos, pois, a nos querer bem, a querer-nos bem assim; olhando-nos assim no encontro: acolher o que nos une, deixar de lado, se houver, algo que pode nos deixar um pouco em dificuldade... Voltando para casa, encontrareis as crianças. Dai-Ihes uma carícia e dizei: "Esta é a carícia do papa". Saibam os aflitos que o papa está com os seus filhos especialmente nas horas da tristeza e da amargura... Adeus, filhos. À bênção acrescento os votos de uma boa noite!"

${ }^{37}$ CHENU, M. D. Diario del Vaticano II: note quotidiane al Concilio 1962-1963. Bologna: Mulino, 1996. 20 de outubro de 1962.

Rev. Pistis Prax., Teol. Pastor., Curitiba, v. 4, n. 2, p. 357-393, jul./dez. 2012 
os mais humildes, os mais pobres e os mais fracos, a afirmação da dignidade do ser humano, os temas da paz e da justiça social, foi divulgada no dia 20 de outubro (FESQUET, 1967, p. 40).

Por disposição expressa de João XXIII ${ }^{38}$, a liturgia foi o primeiro assunto a ser debatido, de 22 de outubro a 13 de novembro. Era, sem dúvida, a questão mais amadurecida do amplo movimento de renovação da Igreja, que desembocara no concílio ${ }^{39}$. Seu esquema preparatório foi também o único que os bispos aceitaram como base para os debates, tendo recolhido sempre uma grande maioria a favor, não obstante a aguerrida resistência de uma minoria, avessa a qualquer mudança.

Dois elementos emergem com toda a evidência: a adoção das línguas atuais na liturgia e a importância da liturgia da Palavra. A autorização para o uso das línguas vernáculas restabelecia o contato entre o culto oficial e o povo (cf. ROSMINI-SEBATI, 1848), que passava a ouvir seus ministros "apregoar em nossas próprias línguas as maravilhas de Deus" (cf. At 2,11). O resgate da mesa da Palavra ao lado da mesa do Pão ${ }^{40}$ superava a monopolização da atenção do povo, dos ministros e dos teólogos em torno da liturgia eucarística (na verdade, a consagração), única parte da missa que se devia "assistir" para cumprir o preceito dominical e festivo. No contexto das reflexões sobre a liturgia, vieram à luz dados teológicos importantes, mas deixados há séculos na sombra: a igreja local; a eucaristia presidida pelo bispo e o presbitério; a participação consciente, ativa e frutuosa dos fiéis. Diante, porém, das inúmeras

${ }^{38}$ Diante do fato inesperado, o cardeal Ottaviani expressou por escrito seu desapontamento ao cardeal Tisserant pela "decisão, comunicada improvisamente, de começar a discussão em concílio em torno da liturgia e não em torno da doutrina da fé, invertendo a ordem já estabelecida no volume dos esquemas entregue aos Padres" (ASV, Vaticano II, Envelope 757, n. 8, Epistolae Em. mi Praesidis ad varios Patres conciliares, Fotocópia (18 de outubro de 1982), ff. 2; apud DE MATTEI, 2011, p. 239.

39 Observa sabiamente Schillebeeckx: "Embora o Concílio não se tenha pronunciado sobre muitas questões que ainda hoje [1965 - n.d.a.] estão sendo discutidas pelos teólogos, tudo o que durante os últimos trinta anos [grosso modo, 1935-1965 - n.d.a.], se fez opinião comum e, pode-se dizer, se tornou parte do sensus fidei contemporâneo, certamente foi aprovado pelo Concílio" (SCHILLEBEECKX, E. A definição tipológica do leigo cristão conforme o Vaticano II. In: BARAÚNA, G. (Org.). A Igreja do Vaticano II. Petrópolis: Vozes, 1965. p. 994).

${ }^{40} \mathrm{Na}$ posse da catedral do Latrão como bispo de Roma, João XXIII centralizara a sua fala justamente nos temas da "palavra" e no "cálice", agora retomados pelo concílio. "[Ele] ressaltou o seu papel de sacerdote ou sumo pontífice, colocando-se emblematicamente entre 0 Cálice e o Livro, entre o sacrifício redentor de Cristo e 0 código da dignidade, da liberdade e da salvação do homem" (CAPOVILLA, 2011, p. 68).

Rev. Pistis Prax., Teol. Pastor., Curitiba, v. 4, n. 2, p. 357-393, jul./dez. 2012 
emendas apresentadas e do desejo de João XXIII de dar tempo para que o concílio fosse atingindo sua própria maturidade, a conclusão dos trabalhos sobre liturgia foi, no dia 19 de novembro, adiada para a próxima sessão do concílio ${ }^{41}$. Arquivava-se, assim, a ideia - ingênua ou maliciosa segundo a qual o concílio seria breve e aprovaria, quase por aclamação, o material preparatório!

Observava-se também que, aos poucos, entre os Padres conciliares, ia se formando uma maioria, quer dizer, um número muito elevado de votos convergentes (aprovando ou rejeitando) sobre os grandes temas do concílio. Esse fenômeno não era programado nem administrado - como querem os encarniçados adversários do Vaticano II; na verdade, os Padres iam progressivamente tomando consciência de seu papel e dos horizontes que o concílio ia descortinando.

Desde o dia 14 de novembro, o concílio tinha iniciado a discussão sobre o projeto das "fontes da revelação". A expressão deixava transparecer a polêmica com a tese protestante da "sola Scriptura", de alguma maneira superada pelo resgate, no âmbito católico, da importância da Bíblia na vida espiritual, na experiência eclesial e na Teologia. De fato, prevalecia a opinião de que só a Palavra de Deus fosse fonte primária da revelação. Quando, depois de acalorados debates, no dia 20 de novembro, foi votado se o esquema podia ser aceito como base para os trabalhos ulteriores, 1.368 padres (sobre um total de 2.109 presentes) se posicionaram contra. De acordo, porém, com o regulamento, eram necessários 2/3 dos votos não só para aprovar um texto, mas também para rejeitá-lo. Sendo assim, o projeto deveria ser o instrumento de trabalho da assembleia. Foi quando, mais uma vez, se manifestou a sabedoria de João XXIII, disposto a salvaguardar a liberdade do concílio. Depois de ouvir Bea, Frings e Liérnart, respeitando a inequívoca vontade da assembleia, o papa decidiu que a maioria necessária para a aprovação de um texto não podia ser exigida

${ }^{41}$ Na votação do dia 14 de novembro de 1962, o esquema sobre a liturgia foi aprovado em princípio - ou seja, como base para os futuros debates e deliberações - por 2162 placet (sim), 46 non placet (não) e 7 cédulas nulas, sinal de que o único esquema não descartado na primeira sessão (primeiro período) do concílio estava em profunda sintonia com a esmagadora maioria dos padres conciliares. Esta votação "anulava o artigo 1257 do código canônico, que atribuía exclusivamente à Santa Sé todas as decisões em matéria de liturgia” (O’MALLEY, JOHN W. Che cosa è successo nel Vaticano II. Milano: V\&P, 2010, p. 141 apud DE MATTEl, 2011, p. 254). 
para rejeitá-lo. (Cf. KLOPPENBURG, 1968, p. 120; CAPOVILLA, 2010, p. 71; PESCH, 2005, p. 9) ${ }^{42}$. Com isso, o texto preparatório foi abandonado, e uma comissão mista, formada por membros da Comissão teológica e do Secretariado para a unidade, foi encarregada de preparar outro. A interpretação papal do regulamento, o crescimento da importância do Secretariado presidido pelo cardeal Bea e a diminuição do peso da Cúria romana aumentavam, de um lado, a preocupação de grupos alinhados com a minoria conciliar e, do outro, a confiança, entre os padres mais abertos, de que uma mudança seria possível.

O cardeal Ottaviani propôs, então, que se discutisse um brevíssimo esquema sobre Maria. Muitos se opuseram à ideia, seja porque lhes parecia estranha a discussão sobre Maria independentemente da reflexão sobre a Igreja, que muitos, aliás, ansiavam por começar. De fato,

o sucesso do concílio parecia estreitamente condicionado pelo modo como a igreja teria definido a si mesma, tanto mais que a reforma litúrgica tinha antecipado alguns grandes nós da concepção da igreja, que corrigiam as impostações excessivamente institucionais e juridicistas dos últimos séculos (ALBERIGO, 2006, p. 52).

Foi assim que, a partir de $1^{\circ}$ de dezembro, durante seis sessões, o concílio se dedicou à discussão do projeto sobre a Igreja. Viu-se que, em apenas dois meses, a consciência conciliar tinha feito passos enormes; a assembleia mostrava-se em condições de exprimir suas próprias convicções e de reconhecer-se em líderes que as materializavam. O projeto sobre a Igreja era dos melhores, mas, mesmo assim, não agradou e recebeu críticas severas: pouca sintonia com a eclesiologia renovada que se vinha construindo desde muito antes do concílio; hegemonia da compreensão societária da igreja, em prejuízo de uma compreensão mistérica; ausência de sensibilidade ecumênica; apresentação do episcopado numa linha de dependência e não de comunhão. As intervenções de Suenens e Montini propunham que toda a obra conciliar girasse em torno de dois

42 "Esta vez, a intervenção decisiva foi de João XXIII... Ela tinha uma importante consequência psicológica: foi consagrada pelo próprio papa a possibilidade de os padres conciliares rejeitarem um esquema proposto pelas comissões romanas... 0 efeito psicológico da 'virada' de 21 de novembro foi enorme. Os progressistas, fortes graças ao apoio do papa, se sentiram pela primeira vez 'maioria”' (DE MATTEl, 2011, p. 263). 
eixos fundamentais: a Igreja "ad intra" e a Igreja "ad extra"; a identidade da Igreja (Ecclesia, quid dicis de te ipsa?) e a missão da Igreja (Ecclesia, quid agis?). Lercaro, numa das últimas sessões, sugeria que a ideia dominante do trabalho conciliar ("o elemento de síntese, o ponto de iluminação e de coerência de todos os temas até aqui tratados") fosse a Igreja dos pobres, tese já levantada por João XXIII. Fizeram-se também inúmeras críticas ao espírito de gueto, triunfalismo e clericalismo subjacentes ao esquema; ao lado da apresentação da igreja como mistério em sentido bíblico-patrístico, propunha-se também a consideração da igreja como povo de Deus.

O debate sobre a Igreja foi um dos momentos mais altos do primeiro período. O concílio interrogava-se sobre as questões de fundo. Os padres crescentemente tomavam consciência de que o evento conciliar não podia se restringir à vida interna da Igreja, mas tinha um horizonte muito mais amplo:

A nova condição da Igreja como comunidade aberta, humanamente indefesa, disponível às necessidades humanas, que o discurso de abertura tinha delineado, ia assumindo contornos cada vez mais precisos e empenhativos. Uma serrada série de intervenções foi deixando claro, de perspectivas diversas, mas complementares, como a consciência cristã contemporânea se caracterizava em modos substancialmente diversos do espírito do esquema preparatório (ALBERIGO, 2006, p. 53).

O esquema preparado pela comissão teológica foi, na verdade, tão "violentamente criticado em sua estrutura, método, argumentação, conteúdo e espírito" (KLOPPENBURG, 1968, p. 38) que nem foi preciso submetê-lo à assembleia para votar sua validade como instrumento de trabalho; foi elegantemente abandonado. Uma nova eclesiologia ia emergindo no horizonte do concílio (ACERBI, 1975).

A última fase da primeira sessão do concílio foi de 23 de novembro a 8 de dezembro. Na pauta, previa-se a discussão de dois projetos: meios de comunicação social e unidade da Igreja. Do primeiro, foi aprovada a substância, com a condição de a comissão reduzi-lo a poucas proposições essenciais. Em relação ao tema da unidade, por falta de coordenação na fase preparatória do concílio, havia três projetos: um preparado pela comissão para as igrejas orientais, numa perspectiva "uniata"; outro, 
elaborado pela comissão teológica; um terceiro, pelo Secretariado para a unidade. Diante desta situação, a questão ecumênica foi, no dia $1^{\circ}$ de dezembro, encaminhada ao exame de uma comissão mista formada pela comissão doutrinal, pela comissão para as igrejas orientais e o Secretariado para a unidade.

\section{Como avaliar o período joanino do concílio?}

Houve luzes e sombras. Dentre as luzes, alguns aspectos se destacam: o clima de liberdade em que os padres conciliares puderam trabalhar; as poucas, mas sábias e oportunas, atitudes tomadas por João XXIII para garantir a liberdade e o bom andamento da assembleia; a rejeição dos textos preparatórios e das manobras curiais; a convocação de teólogos censurados durante o pontificado de Pio XII; o intercâmbio crescente entre os bispos, que fez as experiências de cada um, as diferenças culturais e as diversas sensibilidades contribuírem para um exercício afetivo e efetivo da colegialidade; os contatos, inicialmente casuais, mais tarde programados, entre bispos e teólogos, propiciando um "aggiornamento" teológico antes impensável, dadas as distâncias geográficas, culturais e ideológicas em que ordinariamente os bispos se encontravam; a forma evangélica de João XXIII exercer o ministério petrino. Não faltaram, contudo, sombras: a hegemonia da cúria na comissão teológica e nas comissões temáticas, que, só aos poucos, foi diminuindo; as dimensões da comissão inicial de presidência; certa falta de coordenação dos trabalhos preparatórios; a impressão de que o concílio não tivesse uma agenda clara e não estivesse em condições de chegar a indicações precisas; as pressões e críticas desabonadoras da pessoa de João XXIII e de seu projeto.

A aproximação de uma pausa nos trabalhos conciliares e a doença do papa suscitavam vivas preocupações entre aquelas forças que tinham aderido ao projeto conciliar. Várias iniciativas, porém, foram tomadas, visando à continuidade. Os grupos liderados pelo cardeal Suenens na sua vertente mais teológica; o grupo “Jesus, a Igreja e os pobres”, surgido por iniciativa do ex-padre operário Gauthier e presidido pelo cardeal francês Gerlier, do qual participavam o cardeal Lercaro e Dom Helder Câmara; o grupo 
de Bologna, que, além da liderança de Lercaro, contava com pessoas do peso de Dossetti e Alberigo. Todos esses grupos tomaram iniciativas, visando a garantia de que o trabalho das comissões, durante o longo período de pausa, mantivesse as orientações dadas por João XXIII e compartilhadas por tantos bispos. João XXIII, por seu turno, estabeleceu critérios para que a atividade conciliar prosseguisse entre o primeiro e o segundo período conciliar e criou uma comissão de coordenação (Confalonieri, Döpfner, Liénart, Spellman, Suenens e Urbani) para assegurar um bom andamento do processo conciliar, sobretudo nessa fase de vacância assemblear"4. Finalmente, a carta "Mirabilis ille" do papa a todos os bispos, na Epifania de 1963, deixaria ainda mais explícita e definitiva a sintonização entre o papa e a grande maioria conciliar: "o concílio recebe as suas diretrizes do papa, que o convocou, mas, ao mesmo tempo, cabe aos bispos tutelar o seu livre desenvolvimento... cabe aos padres conciliares propor, discutir, preparar na devida forma as sagradas deliberações" ${ }^{44}$. O clima na assembleia mudara, e, na opinião pública, percebia-se com cada vez maior clareza o alcance do concílio e da virada histórica que estava promovendo. Ao concluir o primeiro período do concílio (8 de dezembro de 1962), João XXIII deixou claro que a suspensão da assembleia não significava "de modo algum a interrupção do trabalho; aliás, aquilo que nos espera será muitíssimo relevante, como certamente não foi em outros concílios durante as pausas... o concílio continua bem aberto nos próximos nove meses de suspensão das sessões ecumênicas propriamente ditas". Ficava clara a disposição do papa de que o concílio tivesse continuidade, recomeçando seus trabalhos no dia 8 de setembro de 1963, com ele ou sem ele.

De fato, foi sem ele, gravemente doente desde $1962^{45}$. Nos primeiros meses de 1963, seu estado de saúde se agravou, o que não o impediu de

${ }^{43}$ Essa comissão, a cujos membros iniciais Paulo VI acrescentou Agagianian, Lercaro e Roberti, se reuniu cinco vezes antes da reabertura do concílio. Na primeira reunião (21 a 27 de janeiro de 1963), reduziu os esquemas preparatórios de setenta e dois a apenas dezessete, reelaborados. Finalmente, o Vaticano II "se libertava da hipoteca constituída pelos trabalhos preparatórios, ainda que muitos elementos e várias formulações produzidos por aqueles trabalhos tenham sido repescados nos textos submetidos sucessivamente ao concílio" (ACERBI, 1975, p. 57).

${ }^{44}$ Mirabilis ille 12.

${ }^{45}$ Em 29 de outubro de 1962 - 18 dias depois de abrir o concílio -, o Vaticano deu a primeira notícia de que o papa tinha uma grave enfermidade no estômago. 
seguir de perto os trabalhos da comissão de coordenação e das comissões conciliares; de receber a filha de Kruschev e seu genro Aleixei Adjubei, redator-chefe do jornal soviético Pravda (7 de março); de publicar a memorável Pacem in terris (11 de abril, quinta-feira Santa), dirigida não só aos fiéis católicos, mas "a todos os homens de boa vontade"; de receber o Prêmio Balzan da Paz (10 de maio); de entoar, pela última vez, na quinta-feira da Ascensão (23 de maio), com voz ainda forte e musical, o Regina Coeli, seguido de aplausos tão prolongados que quase o impediram de dar a bênção.

\section{A morte de um cristão papa}

No dia 28 de maio, ao secretário de Estado que lhe comunica que o mundo inteiro reza por ele, o papa diz:

Dado que o mundo reza pelo papa doente, é bem natural que se dê uma intenção a estas súplicas. Se Deus quer o sacrifício da vida do papa, que isso sirva a impetrar copiosos favores sobre o concílio ecumênico, sobre a Igreja santa, sobre a humanidade que aspira à paz ${ }^{46}$.

A crônica da sua prolongada agonia registrou suas últimas palavras: "Este leito é um altar... Tenho, diante de mim, a visão clara de minha alma, de meu sacerdócio, do concílio, da igreja universal... Estou tranquilo. Sempre desejei fazer a vontade de Deus, sempre, sempre... Quero morrer sem saber se possuo algo que me pertence... O evangelho não mudou, nós é que começamos a entendê-lo melhor... O mundo despertou. Pouco a pouco, a puríssima doutrina da encíclica [Pacem in terris], doutrina exposta com amabilidade, encontrará o caminho das consciências... Não, não me aflijo pelo que se escreveu e se disse de mim. Isso é demasiado pouco em comparação com as angústias de Jesus, Filho de Deus, durante toda a sua vida e na cruz... Deixai-me agora só com o meu Senhor... Ut unum sint. Ut unum sint!"

O desaparecimento do papa - em 3 de junho de 1963, dia de Pentecostes constituiu um evento espiritual que envolveu inesperadamente grande parte da humanidade. Ele tinha aberto um tempo novo na Igreja, tinha

\footnotetext{
46 L'Osservatore Romano, 29 de maio de 1963.
} 
reproposto os temas essenciais da caridade e da unidade, estreitamente ligados aos da renovação da atitude espiritual, das estruturas eclesiais, mas também da reformulação da doutrina (ALBERIGO, 2006, p. 61).

\section{Alguns testemunhos}

Muitos que, diante da escolha e dos primeiros dias do pontificado de João XXIII, se mostravam decepcionados e à espera de, quem sabe, um Pio XIII - pois Pio XII, para muitos, era inexcedível - foram aos poucos revendo suas posições e reconhecendo a impropriedade de suas avaliações anteriores ${ }^{47}$, tendo chegado uns a, finalmente, expressar um amor de paixão pelo Papa do Concílio.

O testemunho de Alceu Amoroso Lima, neste sentido, é modelar. Uma das suas primeiras reações:

Dois ou, antes, três grandes papas [Pio XI, Pio XII e 'Pio XIII'], um logo em seguida do outro, era talvez uma medicina forte demais para a Igreja e para o mundo. Vamos respirar um pouco. Vamos fumar um cigarrinho. Vamos esticar as pernas. Vamos dar uma volta no foyer durante o intervalo. O nosso bom João XXIII, o meu gordo e bonachão xará, vai permitir que a gente respire um pouco, depois deste mundo de coisas que Pio XII jogou, constantemente, e a todo propósito, sobre as nossas cabeças... João XXIII é um intervalo, um descanso, um banco, um copo d'água, uma cadeira de balanço, depois desta tremenda corrida que Pio XI e Pio XII nos obrigaram a fazer. Andávamos de língua de fora. O Espírito Santo viu isto lá de cima. E decidiu bater o gongo para anunciar um tempo de repouso. São as caminhadas que levam a Igreja a construir o Reino de Deus, sem dúvida. Mas para caminhar é preciso tomar fôlego, e o meu bondoso xará vai nos deixar tomar fôlego, dando tempo a que se faça um pouco o balanço da obra imensa de seus dois predecessores ${ }^{48}$.

${ }^{47}$ Carta de Alceu Amoroso Lima à sua filha beneditina, Maria Teresa Amoroso Lima: "E que lição para nós que depositamos nele tanta esperança, depois de o considerarmos, a princípio, como uma... saída, para 0 impasse da eleição. Revelou-se, nestes quatro anos, um homem providencial para a Igreja, para o mundo, e correspondendo de tal maneira a tudo o que alguns de nós, do fundo do coração, desejávamos..." (Rio, 23 de dezembro de 1962). In: LIMA, A. A. João XXIII. Rio de Janeiro: Livraria José Olympio, 1966. p. 102.

${ }^{48}$ Carta de Alceu de Amoroso Lima à sua filha (Nova York, 29 de outubro de 1958) LIMA, 1966, p. 12. Nas citações seguintes da mesma obra, constarão apenas a cidade onde a carta foi escrita, a data da mesma e 
Algum tempo depois do lançamento da Mater et Magistra: "Os meios vaticanos estão impregnados do mais perfeito conservadorismo. E João XXIII, para lançar a Mater et Magistra, deve ter ouvido somente a voz do Espírito Santo e feito um verdadeiro milagre para sair da engrenagem" 49 . Comentando o eco, na imprensa francesa, da alocução de abertura do concílio: “... a 'revolução' que o papa provocou com seu discurso que todo mundo esperava fosse uma alocução convencional e acabou sendo uma 'bomb' com a condenação dos 'integristas' e 'conservadores'... 50" Pedindo à comunidade de sua filha beneditina orações pela saúde de Roncalli ${ }^{51}$, "para nós duplamente importante, por ser o papa e por ser... João XXIII. Se ele vier a faltar bem no meio do concílio, ou antes, enquanto o concílio não decidir

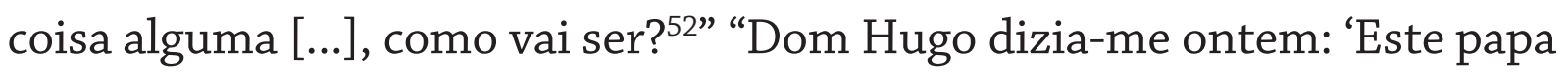

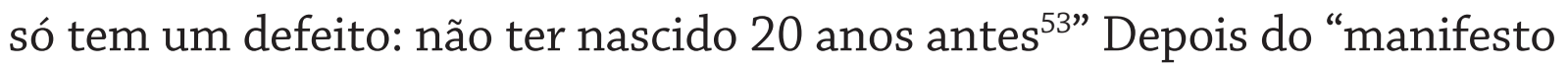
dos bispos": "Quando é que o nosso episcopado escreveria o que aí está, se não fosse o nosso João XXIII? ${ }^{54 ”}$ Na véspera da morte de João XXIII: “... o novo rumo que o nosso 'bom João' imprimiu à barca, morrendo cercado de amor e de respeito de todos e recolocando a Igreja nos passos de Jesus e de João..." 55 . No dia seguinte: "Seja como for, será impossível um novo papa tão afinado com o que julgo ser a linha que mais convém à Igreja neste momento, como o que acabou de deixar-nos ${ }^{56 "}$ Alguns dias mais tarde: "De qualquer modo, o que fez o nosso João XXIII ninguém poderá desfazer... Um santo que abriu o século XXI" ${ }^{57}$. E para concluir, as perguntas que se faziam um dia antes do sepultamento de João XXIII:

\footnotetext{
a página da obra de Alceu já citada.

${ }^{49}$ Roma, 10 de outubro de 1962, p. 84.

${ }^{50}$ Roma, 15 de outubro de 1962, p. 89.

${ }^{51}$ Cf. nota 76.

${ }^{52}$ Paris, $1^{\circ}$ de dezembro de 1963, p. 96.

${ }^{53}$ Bordo do Augustus, 9 de dezembro de 1962, p. 99.

${ }^{54}$ Rio, 3 de maio de 1963, p. 114. 0 que o autor chama de "manifesto dos bispos" é a Mensagem do Episcopado Brasileiro por ocasião do $1^{\circ}$ de Maio de 1963 (cf. LIMA, 1966, 216).

55 LIMA, A. A., Rio, 2 de junho de 1963, p. 119.

${ }^{56}$ LIMA, A. A., Rio, 4 de junho de 1963, p. 121.

${ }^{57}$ LIMA, A. A., Rio, 7 de junho de 1963, p. 123.
} 
Por mais que procure calar a voz das minhas cavernas, não consigo tirar o pensamento do que foram esses quatro anos e meio que fizeram progredir a Igreja de 400 anos! ... Quando penso nesses quatro anos, começo a considerá-los como algo de irreal, de trop beau pour être vrai. E fico pensando: será que realmente vivemos esses quatro anos? Será que realmente houve um homem chamado João XXIII? ${ }^{58}$.

\section{Referências}

ACERBI, A. Due ecclesiologie: ecclesiologia giuridica ed ecclesiologia di comunione nella Lumen Gentium1. Bologna: Dehoniane, 1975.

ALBERIGO, G. (Org.). Jean XXIII devant l'histoire. Paris: Éd. du Seuil, 1989.

AlBerigo, G. (Org.). História dos Concílios Ecumênicos. São Paulo: Paulus, 1995.

ALBERIGO, G. (Org.). Storia del Concilio Vaticano II. Bologna: Il Mulino, 1995-2001. v. 5.

ALBERIGO, G. Papa Giovanni (1881-1963). Bologna: EDB, 2000.

ALBERIGO, G. Breve storia del Concilio Vaticano II (1959-1965). Bologna: Il Mulino, 2006.

ALBERIGO, G.; GIOVANNI XXIII, A. Profezia nella fedeltà. Brescia: Queriniana, 1978.

ALBERIGO, G.; MELLONI, A. Fede, tradizione, profezia: studi su Giovanni 23 e sul Vaticano 2. Brescia: Paideia, 1984.

AMERIO, R. Iota unum: studio delle variazioni della chiesa cattolica nel secolo XX. Milano: Ricardo Ricciardo, 1985.

AUBERT, R. Vatican I. Paris: L'Orante, 1964.

BENIGNI, M.; ZANCHI, G. João XXIII. São Paulo: Paulus, 2000.

\footnotetext{
${ }^{58}$ Lima, Rio, 16 de junho de 1963, p. 129.
} 
BEOZZO, J. O. A Igreja do Brasil no Concílio Vaticano II (1959-1965). São Paulo: Paulinas, 2005.

BERGER, D. Gegen die Tradition oder im Licht der Tradition? Zu neueren Interpretationen des Zweiten Vatikanischen Konzils. Divinitas, v. 40, p. 294316, 2005.

CAPOVILLA, L. F. Ricordi dal concilio: siamo appena all'aurora. Brescia: La Scuola, 2011.

CERETTI, G. Molte chiese cristiane, un'unica Chiesa di Cristo: corso di ecumenismo. Brescia: Queriniana, 1992.

CHENU, M. D. Diario del Vaticano II: note quotidiane al Concilio 1962-1963. Bologna: Il Mulino, 1996.

CONGAR, Y. Le Concile de Vatican II: son Église peuple de Dieu et corps du Christ. Paris: Beauchesne, 1984.

DE MATTEI, R. Il Concilio Vaticano II: uma storia mai scritta. Torino: Lindau, 2011.

DISCURSO do Papa João XXIII na abertura solene do Concílio. 1962. Disponível em: <http://www.presbiteros.com.br/site/discurso-do-papa-joao-xxiii-na-abertura-solene-do-concilio/>. Acesso em: 20 jul. 2010.

DOSSETTI, G. Il Vaticano II: frammenti di una riflessione. Bologna: EDB, 1996.

FAPPANI, A.; MOLINARI, F. (Ed.). Giovanni Battista Montini Giovane, 1897-1944: documenti inediti e testimonianze. In: BENIGNI, M.; ZANCHI, G. João XXIII. São Paulo: Paulus, 2000. p. 5-7.

FESQUET, H. Diario del Concilio. Milano: Mursia, 1967.

GENNARI, G. Quando Ratzinger era considerato un 'pericoloso teologo d'oltralpe'. Disponível em: 〈http://affaritaliani.libero.it/roma/teologo_benedetto_ xvi_intervista110311.html>. Acesso em: 25 mar. 2011.

GHERARDINI, B. Concilio Vaticano II. Un discorso da fare. Frigento: Casa Mariana, 2009. 
GIOVANNI XXIII, A. Giornale dell'Anima e altri scritti spirituali. Cinisello Balsamo: San Paolo, 1989.

HINSCHIUS, P. Kirchenrecht. Berlin: I. Guttentag, 1883. Tomo III.

JOÃO XXIII. Allocuzione del Santo Padre Giovanni XXIII con la quale annuncia il Sinodo romano, il Concilio ecumenico e l'aggiornamento del Codice di Diritto canonico. AAS, v. 51, p. 65-69, 1959.

JOÃO XXIII. Encíclica ad Petri Cathedram. 29 de junho de 1959. Disponível em: <http://www.vatican.va/holy_father/john_xxiii/encyclicals/documents/ hf_j-xxiii_enc_29061959_ad-petri_po.htmb. Acesso em: 20 jul. 2010.

JOÃO XXIII. Constituição apostólica Humani Salutis. 25 de dezembro de 1961. Disponível em: <http://www.vatican.va/holy_father/john_xxiii/apost_constitutions/documents/hf_j-xxiii_apc_19611225_humanae-salutis_po.html>. Acesso em: 20 jul. 2010.

JOÃO XXIII. Radiomessaggio a tutti i fedeli cristiani ad un mese dal Concilio Ecumenico Vaticano II. 11 de setembro de 1962.

JOÃO XXIII. Discorsi Messaggi Colloqui di Giovanni XXIII. Roma: Libreria Editrice Vaticana, I. [DMC, I].

JOÃO XXIII. Discorsi Messaggi Colloqui di Giovanni XXIII. Roma: Libreria Editrice Vaticana, I. [DMC, II].

JOÃO XXIII. Discorsi Messaggi Colloqui di Giovanni XXIII. Roma: Libreria Editrice Vaticana, III. [DMC, III].

JOÃO XXIII. Discorsi Messaggi Colloqui di Giovanni XXIII. Roma: Libreria Editrice Vaticana, IV. [DMC, IV].

JOÃO XXIII. Discorsi Messaggi Colloqui di Giovanni XXIII. Roma: Libreria Editrice Vaticana, V. [DMC, V].

JOÃO XXIII. Carta apostólica. Mirabillis ille. 6 de janeiro de 1963. Disponível em: <http://www.vatican.va/holy_father/john_xxiii/letters/documents/hf_j-xxiii_ let_19630106_mirabilis_po.html>.Acesso em: 20 jul. 2010. 
KLOPPenBURG, B. Compêndio do Concílio Vaticano II: constituições, decretos, declarações. Petrópolis: Vozes, 1968.

LIMA, A. A. João XXIII. Rio de Janeiro: José Olympio, 1966.

MARCHETTO, A. Il Concilio Ecumenico Vaticano II: contrappunto per la sua storia. città del Vaticano: Libreria Editrice Vaticana, 2005.

MELLONI, A. Fede, tradizione, profezia: studi su Giovanni 23 e sul Vaticano 2. Brescia: Morcelliana, 1984.

MELLONI, A. Formation et développement de la culture de Roncalli. In: ALBERIGO, G. (Org.). Jean XXIII devant l'histoire. Paris: Éd. du Seuil, 1989. p. 219-259.

MELLONI, A. Tensioni e timori nella preparazione del Vaticano II. La "Veterum sapientia” di Giovanni XXIII (22 febbraio 1962). Cristianesimo Nella Storia, v. 11, p. 275-307, 1990.

MELLONI, A.; RUGGIERI, G. (Org.). Chi ha paura del Vaticano II? Roma: Carocci, 2009.

PESCH, O. H. Il Concilio Vaticano II: preistoria, svolgimento, risultati, storia post-conciliare. Brescia: Queriniana, 2005.

RADIOMESSAGGIO a tutti i fedeli cristiani ad un mese dal Concilio Ecumenico Vaticano II (11 settembre 1962). Disponível em: <http://www.vatican.va/ holy_father/john_xxiii/messages/pont_messages/1962/documents/hf_j-xxiii_ mes_19620911_ecumenical-council_it.html>. Acesso em: 20 jul. 2010.

RONCALLI, M. Giovanni XXIII, Angelo Giuseppe Roncalli: una vita nella storia. Milano: Mondadori, 2006.

SCHATZ, K. Storia dei concili: la chiesa nei suoi punti focali. Bologna: EDB, 1999.

SCHILLEBEECKX, E. A definição tipológica do leigo cristão conforme o Vaticano II. In: BARAÚNA, G. (Org.). A Igreja do Vaticano II. Petrópolis: Vozes, 1965. p. 981-1000. 
THILS, G. L'ecclesiologia del concilio Vaticano I: preparazione, risultati, problemi, dans L'ecclesiologia dal Vaticano I al Vaticano II. Milão: La Scuola, 1972. WILTGEN, R. Le Rhin se jette dans le Tibre: le concile inconnu. Paris: Editions du Cèdre, 1976.

Recebido: 21/11/2011

Received: 11/21/2011

Aprovado: 27/01/2012 Approved: 01/27/2012 